\title{
SENTIDOS DA PREGUIÇA BAIANA EM REPORTAGEM DO JORNAL NACIONAL: ENTRE O MESMO E O NOVO
}

\section{MEANING EFFECTS IN A JORNAL NACIONAL NEWS REPORT: BETWEEN THE SAME AND THE NEW}

\author{
Débora de Jesus Conceição ${ }^{1}$ \\ Universidade do Estado da Bahia(UNEB)
}

\section{RESUMO}

Este artigo analisa uma reportagem veiculada pelo Jornal Nacional no dia quinze de outubro de 2011, em que o assunto principal foi a opinião da população baiana diante da adoção do horário de verão naquele ano. Os efeitos de sentido analisados oscilaram entre a imagem do baiano trabalhador e a do baiano preguiçoso, comprovando a heterogeneidade discursiva resultante do atravessamento desse material por diferentes formações discursivas. Os efeitos de sentido depreendidos confirmam o posicionamento da Análise do Discurso de linha francesa, quanto à possibilidade de o mesmo ou o novo se firmarem no processo ininterrupto de significação.

PALAVRAS-CHAVE: Jornal Nacional; efeitos de sentido; heterogeneidade discursiva; preguiça baiana.

\begin{abstract}
This article intends to analyze a report published by Jornal Nacional on October 15, 2011 in which the main topic is the opinion of people from Bahia about the adoption of 'daylight saving time' in the same year. The meaning effects analyzed oscillated between the image of working and lazy people from Bahia, conffirming the discursive heterogeneity resulted from the crossing of this material by different discursive formations. The meaning effects confirm the position of the french Discourse Analysis as to the possibility of the same or the new being established in the uninterrupted process of signification.
\end{abstract}

KEY-WORDS: Jornal Nacional; meaning effects; discursive heterogeneity; laziness of "baianos".

\section{INTRODUÇÃO}

De acordo com Orlandi (2001), o funcionamento discursivo não se resume a uma repetição de discursos anteriores, ele envolve também uma construção de novos sentidos, os quais são atravessados por sentidos anteriores, cujos efeitos de sentido podem ser outros. Um enunciado nunca se repete de forma idêntica e, assim como há deslocamentos espaço-temporais, há igualmente deslocamentos semântico-discursivos.

O dizer historicizado remete a uma memória que o estabilizou pela repetição, sem, contudo, nunca ter deixado de ser suscetível a deslizes, podendo transformar-se em um outro, tendo em vista que os sentidos não são controláveis. Orlandi (2001) afirma que repetição/reprodução e repetição/transformação são constitutivos do processo discursivo e dos sentidos. Dessa forma, toda repetição acarreta uma "mexida nas redes de filiações dos sentidos" dos já-ditos, dos dizeres estabilizados (ORLANDI, 2001, p. 36). Ainda segundo a autora, é entre o mesmo e o diferente, ou

\footnotetext{
${ }^{1}$ Mestre em Estudos de Linguagens pela Universidade do Estado da Bahia (UNEB). Este trabalho é parte da dissertação de mestrado realizada no biênio 2012-2014. E-mail: debora.conceicao@jna.ifmt.edu.br
} 
dito de outro modo, é "entre o já-dito e o a se dizer que os sujeitos e os sentidos se movimentam, fazem seus percursos, (se) significam".

Assim como os sentidos, as identidades não são construtos fixos. Elas se baseiam no funcionamento da memória, a qual, do mesmo modo que faz uma retomada dos acontecimentos, traz o novo, o impensado. Isto posto, torna-se possível observar uma alternância entre a identidade estereotipada da baianidade e os sentidos polissêmicos presentes nessa relação, fazendo emergirem sentidos inesperados, refletindo o movimento possível de desterritorialização das identidades.

A reportagem que será analisada aqui foi ao ar no dia 15 de outubro de 2011 e transmitida em horário nobre pelo Telejornal Jornal Nacional tratando sobre a opinião dividida da população baiana entre concordar ou não com a adoção do horário de verão. A escolha pelo Jornal Nacional justifica-se pela sua posição de destaque dentro da Rede Globo: é o programa mais tradicional, mais emblemático e mais importante inserido na programação da emissora hegemônica do País, além de ter sido o primeiro programa transmitido nacionalmente em tempo real, no ano de 1969. O Jornal Nacional nasce imbuído da missão de ser o "telejornal da nação brasileira", unindo os brasileiros de diferentes partes do país, um país de dimensões continentais, mas cujo povo apesar de toda a diversidade, principalmente cultural, se vê representado na tela de televisão como um só povo. O atual slogan da emissora - "Globo: a gente se vê por aqui" - deixa claro o propósito da emissora de ser uma ferramenta ideológica imbuída do projeto de representação do povo brasileiro.

Sobre a ideia que se tem do baiano como indivíduo preguiçoso presente na referida reportagem, vale ressaltar que se trata de uma representação defendida, inclusive, por alguns baianos como "uma forma peculiar de estar no mundo" (ZANLORENZI, 1998, p. 31). Assim, a preguiça acaba sendo ressignificada e positivada, dando sustentação a outros sentidos, adaptados ao novo contexto socioeconômico do Estado, ajudando a compor o imaginário de um local único, sem igual no território brasileiro: sinônimo de descanso, de despreocupação, lugar em que o corpo não é castigado com as obrigações do trabalho.

Segundo a antropóloga Elisete Zanlorenzi (1998), em sua tese de doutorado O mito da preguiça baiana, a representação do baiano preguiçoso começou a ser fortalecido com a intensificação das ondas migratórias para o eixo Rio-São Paulo. A partir desse momento emerge, justamente em contraste com o estereótipo negativo (baiano preguiçoso), o estereótipo positivo (paulista trabalhador). A projeção artístico-cultural da Bahia para o restante do país contribuiu para sedimentar essa ideia, por meio de representações diversas, dentre as quais está a música popular brasileira. A canção Tarde em Itapuã (1972), de autoria de Vinicius de Moraes e Toquinho, é um desses recursos que ajudaram a construir esse imaginário:

\author{
Um velho calção de banho \\ O dia pra vadiar \\ Um mar que não tem tamanho \\ E um arco-íris no ar \\ Depois na praça Caymmi \\ Sentir preguiça no corpo \\ E numa esteira de vime \\ Beber uma água de coco [...] \\ (VINÍCIUS DE MORAES; TOQUINHO, 1972)
}

As análises feitas fundamentam-se na premissa oriunda da Análise do Discurso (AD), a de que é a ideologia que fornece as evidências capazes de levar a crer na naturalidade do que, na verdade, é produzido historicamente. 


\section{A memória discursiva na perspectiva da Análise do Discurso}

A partir da segunda fase da AD (Análise do Discurso), o sujeito deixa de ser visto como resultado de uma interpelação sem falha, sujeito pleno, submetido sem resistência à maquinaria discursiva. A resistência passa a ser concebida como parte constitutiva do assujeitamento, afinal "é preciso ousar se revoltar. (...) é preciso ousar pensar por si mesmo” (PÊCHEUX, 1997b, p. 304). O sujeito passa a ser pensado a partir do exterior, e, nesse sentido, tanto interdiscurso quanto préconstruído são conceitos mobilizados para explicar o primado "do outro" sobre "o mesmo". A maquinaria discursiva fechada é substituída pelo entendimento de "uma [formação discursiva] FD (que) não é um espaço estrutural fechado, pois é constitutivamente 'invadida' por elementos que vêm de outro lugar (isto é, de outras FDs) que se repetem nela" (PÊCHEUX, 1997a, p. 314).

Pêcheux, em suas últimas obras, não mais considera o sujeito como puro efeito de interpelação ideológica. A formação discursiva deixa de ser vista como espaço que reflete um assujeitamento total, pois já não é mais acreditada como um espaço fechado, pois é "invadida" por outras formações discursivas. Já não são mais as formações discursivas e as relações que mantêm entre si que produzem o sentido, e sim o interdiscurso.

A partir de conceitos como pré-construído, interdiscurso e intradiscurso, Pêcheux vai desenvolver o que ele chamou de "fio discursivo". Segundo o autor, a discursividade funciona como um fio discursivo capaz de ligar o intradiscurso ao interdiscurso, um fio constantemente tensionado pela possibilidade de o mesmo ou o novo se firmarem no processo ininterrupto de significação, mostrando ao sujeito que ele não é início nem fim do dizer. O sujeito é convocado a "andar" nesse fio, retomando discursos produzidos anteriormente, em outros lugares, por enunciadores que desconhece, e que talvez nunca chegue a conhecer, mas que o tocam.

O primeiro conceito que Pêcheux utilizou para desenvolver o que chamou de fio discursivo foi o pré-construído. O pré-construído é uma "construção anterior, exterior, mas sempre independente, em oposição ao que é construído pelo enunciado. Trata-se, em suma, do efeito discursivo ligado ao encaixe sintático" (PÊCHEUX, 1997b, p. 99). Tanto em Paul Henry (1993)linguista precursor do termo- quanto em Michel Pêcheux (1997), esse conceito se une à "articulação dos enunciados", que é como o elo entre o discurso recente e o discurso “já-lá". O pré-construído é assimilado pelo sujeito enunciador no processo de seu assujeitamento ideológico, ou seja, quando é tocado pela ilusão de que é fonte de seu discurso. O sujeito desconhece que é, desde sempre, assujeitado à memória discursiva, ao interdiscurso. O pré-construído reflete a presença de sentidos produzidos no passado, mas que se instauram no acontecimento discursivo presente, refletindo a forma como o sujeito pensa, age e diz no "agora".

Daí decorre a necessidade de investigar o funcionamento do interdiscurso, definido por Pêcheux (1997) como:

(n)o fato de que algo fala sempre antes, em outro lugar e independentemente, isto é, sob a dominação do complexo das formações ideológicas (...), ele é o todo complexo dominante das formações discursivas, esclarecendo que também ele é submetido à lei de desigualdade-contradição-subordinação (PÊCHEUX, 1997b, p. 162).

Orlandi (1999, p. 33), em consonância com Pêcheux, conceitua interdiscurso como: “[...] todo conjunto de formulações já feitas e já esquecidas que determinam o que dizemos". É o dizível, histórica e linguisticamente definido; o enunciável, o já-dito, exterior à língua e ao sujeito, mas que está no domínio da memória discursiva. Logo, para que algo tenha sentido, é preciso que tenha havido um já-dito sustentando o que é dito no presente pelo sujeito enunciador.

É do interdiscurso que as formações ideológicas proverão as formações discursivas de sentidos que refletem o fato de que alguma coisa fala antes, em outro lugar, de forma independente, mas que, apesar disso, confere ao sujeito a impressão da evidência dos sentidos. A intrincação do funcionamento interdiscursivo com as várias formações ideológicas "fornece a cada sujeito sua 
realidade, enquanto sistema de evidências e de significações percebidas-aceitas-experimentadas" (PÊCHEUX, 1997b, p. 162).

É ainda o interdiscurso que fornecerá ao enunciador os objetos (já-ditos) de que se apropriará para, em seguida, torná-los objetos de seu próprio discurso, de forma coerente. Em Análise do Discurso, o interdiscurso tem sido identificado como memória discursiva, uma espécie de "memória social" afetada pelo esquecimento e que emerge na materialidade textual, nos gestos de interpretação, produzindo efeitos de regularidade na produção dos sentidos. Pêcheux (2002) vem substituir o que chama de interdiscurso por redes de memória, o que mais tarde veio a se configurar como "memória discursiva".

[...] a memória discursiva seria aquilo que, face a um texto que surge como acontecimento a ler, vem re-estabelecer os implícitos (quer dizer, mais tecnicamente, os pré-construídos, elementos citados e relatados, discursos transversos; etc.) de que sua leitura necessita: a condição legível em relação ao próprio legível-(PÊCHEUX, 1999, p. 52).

\title{
2. A memória abrindo possibilidade para o mesmo e para o novo
}

A memória discursiva é território de lembranças e apagamentos; afinal, é uma "memória afetada pelo esquecimento" (ORLANDI, 1999, p. 34). Esse esquecimento é de natureza inconsciente, efeito da interpelação ideológica. É a ideologia que apaga o processo histórico no qual os sentidos se formam e adquirem significado, criando a ilusão de que as palavras têm um sentido imanente e, portanto, nela estão fixos. O sujeito se constitui no/pelo esquecimento, pois é tocado pelo inconsciente e pela ideologia. Além disso, esses apagamentos - ou esquecimentos refletem a impossibilidade de o sujeito ter controle sobre os efeitos de sentidos provindos do interdiscurso, levando-o a se inscrever numa posição discursiva da memória do dizer. Os apagamentos são necessários, pois dão espaço para as lembranças, a memória efetivamente mobilizada pelo sujeito.

Sobre a reinscrição e posterior ressignificação do já-dito fornecido pela memória, Pêcheux (1999) traz a seguinte afirmação:

\begin{abstract}
A memória tende a absorver o acontecimento, como uma série matemática prolonga-se conjeturando o termo seguinte em vista do começo da série, mas o acontecimento discursivo, provocando interrupção, pode desmanchar essa 'regularização' e produzir retrospectivamente uma outra série sob a primeira, desmascarar o aparecimento de uma nova série que não estava constituída enquanto tal e que é assim o produto do acontecimento; o acontecimento, no caso, desloca e desregula os implícitos associados ao sistema de regularização anterior (PÊCHEUX, 1999, p. 52).
\end{abstract}

Em Análise do Discurso, a paráfrase está do lado da produtividade, é a variação do mesmo, ou, dito de outro modo, "'é a matriz do sentido, pois não há sentido sem repetição, sem sustentação no saber discursivo" (ORLANDI, 1999, p. 38). Em relação à constituição das identidades, é a paráfrase que regula, por meio de constantes reiterações, os sistemas de representação que constituem o conhecimento social capaz de orientar o comportamento dos indivíduos e a forma como estes são percebidos pelo outro. Por outro lado, a polissemia torna possível que o novo, o inesperado irrompa, "pois se os sentidos - e os sujeitos - não fossem múltiplos, não pudessem ser outros, não haveria necessidade de dizer" (ORLANDI, 1999, p. 38).

De acordo com Pêcheux (1997), há uma relação entre interdiscursividade e paráfrase. Essa relação reflete o apagamento da rede parafrástica exterior a uma FD, o que leva o sujeito a apagar outras possibilidades de formulação, criando nele a ilusão de unicidade na formulação do dizer, como se não pudesse dizer outra coisa e de outra maneira (esquecimento $\mathrm{n}^{\circ} 2$ ). O sujeito, comprometido com os sentidos autorizados de sua formação discursiva, desconhece ou não reconhece os sentidos provenientes de outras formações discursivas, o que provoca nele o efeito 
de unicidade. O exterior da formação discursiva é, dessa maneira, esquecido, apagado pelo sujeito, o qual passa a reproduzir um discurso-base pré-existente, numa atividade de reformulação de jáditos, numa relação parafrástica:

Todo sujeito-falante "seleciona" no interior da formação discursiva que o domina, isto é, no sistema de enunciados, formas e sequências que nela se encontram em relação de paráfrase - um enunciado, forma ou sequência, e não um outro que, no entanto, está no campo daquilo que poderia reformulá-lo na formação discursiva considerada (PÊCHEUX, 1997b, p. 173).

Os funcionamentos parafrástico e o metafórico estão imbricados na constituição dos sentidos. Orlandi (2005, p. 78) esclarece que "é a paráfrase (pensada em relação à configuração das formações discursivas) que está na base da noção de deriva que, por sua vez, se liga ao que é definido como efeito metafórico". Orlandi (1990) diz ainda que os limites entre o mesmo e o diferente são bastante tênues. A metáfora, para a autora, é uma palavra tomada por outra. Já a paráfrase é "o uso diferente do mesmo, do outro no um" (ORLANDI, 1990, p. 44).

Em poucas palavras, poderíamos dizer que metáfora é transferência, polissemia é o movimento de sentido e paráfrase é a contenção do mesmo sentido. Tanto os sentidos quanto os sujeitos se movimentam pelo imbricamento desses processos metafóricos, parafrásticos e polissêmicos.

A linguagem funciona ora pela recorrência do mesmo, ora pela possibilidade do diferente. Entender como os discursos funcionam significa considerar um "duplo jogo da memória" que, assim como pode cristalizar, estabilizar pela repetição histórica, pode tornar possível que o diferente, o inesperado venha a emergir no discurso. São as condições de produção (tanto imediata quanto a que se relaciona com a historicidade) que determinam ora a repetição de sentidos, ora a sua reformulação. Isso significa afirmar que os enunciados produzidos são relativos, errantes e instáveis e estão permanentemente sendo reconfigurados. Abre-se, então, espaço para a desregulação que, de acordo com Pêcheux, significa que "todo enunciado é suscetível de tornar-se outro, diferente de si mesmo, se deslocar discursivamente de seu sentido para derivar para um outro" (PÊCHEUX, 2002, p. 53).

Acontece que, num determinado momento histórico, algumas ideias são ressaltadas, enquanto outras são caladas ou até renovadas. Por exemplo, nem sempre a afrodescendência baiana foi algo orgulhosamente enfatizado, ao contrário, houve um tempo em que a elite branca baiana ignorava a existência social do negro. A presença do elemento negro afastava a Bahia de um projeto de aproximação com a Europa, como ocorreu no Rio de Janeiro e em São Paulo. Hoje, a cultura negra está no centro da identidade baiana.

O funcionamento interdiscursivo opera, segundo Pêcheux (1997), a partir de dois eixos: o da formulação (horizontal) e o da constituição (vertical). Já foi aqui abordado o eixo da constituição dos dizeres, que é o interdiscurso. O intradiscurso, o eixo da formulação, é exatamente a materialidade discursiva obtida quando o sujeito produz discurso a partir de uma formação discursiva a qual lhe fornece a matéria-prima em forma de "já-ditos" provindos do interdiscurso. É o que se afirma nas palavras de Pêcheux (1997):

O intradiscurso, enquanto "fio do discurso" do sujeito é, a rigor, um efeito do interdiscurso sobre si mesmo, uma "interioridade" inteiramente determinada como tal do "exterior". E o caráter da forma sujeito, com idealismo espontâneo que ela encerra, consistirá precisamente em reverter a determinação: diremos que a forma-sujeito (pela qual o "sujeito do discurso" se identifica com a formação discursiva que o constitui) tende a absorver-esquecer o interdiscurso no intradiscurso, de modo que o interdiscurso aparece como puro "já-dito" do intra-discurso, no qual ele se articula por "co-referência" (PECHÊUX, 1997b, p. 167). 
Courtine e Marandin $(1980)^{2}$ investigam uma memória que chamaram de repetição vertical. Ao contrário do que chamaram de "memória cheia, saturada", que diz respeito à repetição de elementos por extensão, a "memória lacunar ou com falhas" é "uma repetição vertical, que não é aquela da série de formulações que foram enunciadas, mas o que se repete a partir disso, um não sabido, um não reconhecido e deslocado, deslocando-se no enunciado" (COURTINE; MARANDIN, 1981, p.27-28), que ocorre à revelia do enunciador, sob influência da História, abrindo a possibilidade para que a matéria "esburaque-se", perfure-se antes de se desdobrar em paráfrase. Courtine apresenta tal questão da seguinte forma:

\footnotetext{
Existem, portanto, dois modos de determinação do ato de enunciação pela exterioridade do enunciável, ou interdiscurso: o interdiscurso como preenchimento, produtor de um efeito de consistência no interior do formulável, e o interdiscurso como oco, vazio, deslocamento, cuja intervenção provoca um efeito de inconsistência (ruptura, descontinuidade, divisão) na cadeia do reformulável (COURTINE, 1999, p. 22).
}

Os autores relacionam esquecimento ao apagamento referencial, apagamento da memória dos saberes históricos e sociais e que resulta numa repetição que é, ao mesmo tempo, presente e ausente: "ausente porque ela funciona aí sob o modo de desconhecimento, e presente em seu efeito, uma repetição na ordem de uma "memória lacunar e com falhas" (COURTINE, 1999, p. 21). Memória e esquecimento são, portanto, essenciais para a investigação dos efeitos de sentido na materialidade textual a que me propus.

\section{Análise}

$\mathrm{Na}$ reportagem, que foi ao ar no dia 15 de outubro de 2011 e que tratou da adoção do horário de verão na Bahia, a opinião dividida da população baiana entre concordar ou não com tal horário reflete a heterogeneidade de sentidos que ora fortalece o mito do "baiano preguiçoso", ora desvela um sentido inesperado, ao final da reportagem: o baiano trabalhador que acorda cedo para cumprir com suas obrigações. Importa esclarecer que a reportagem analisada foi obtida por meio de pesquisa no site do Jornal Nacional e é a materialização escrita do que foi dito pelos jornalistas que apresentaram o telejornal na referida data.

\footnotetext{
${ }^{2}$ Durante colóquio Materialidades Discursivas, realizado em 1980 entre os dias 24 e 26 de abril na Universidade de Paris.
} 


\title{
Jornal Nacional
}

T1

Edição do dia 15/10/2011

15/10/2011 21h58 - Atualizado em 15/10/2011 21h58

\section{Horário de verão começa à Oh deste sábado (15) em 11 estados e no DF}

A novidade, este ano, é a inclusão da Bahia. Metade dos baianos ouvidos em uma pesquisa concordou com o horário de verão.

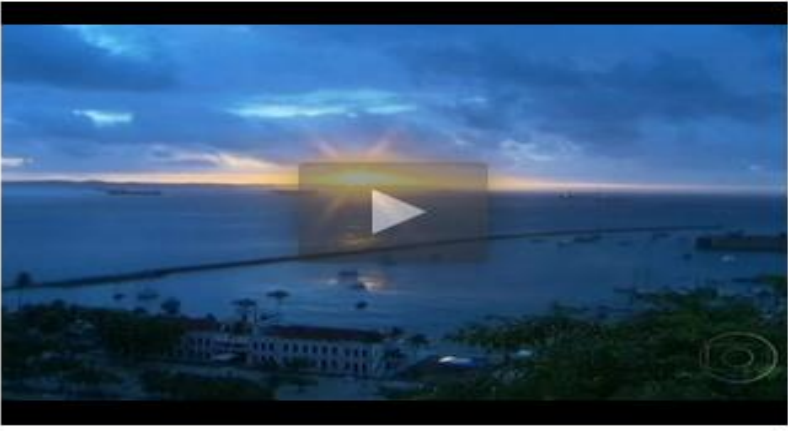

Bitencourt.
O horário de verão começa neste sábado (15) à Oh em 11 estados e no Distrito Federal. A novidade, este ano, é a inclusão da Bahia.

Os baianos sempre gostaram dos dias mais longos do verão. Mas quando se fala em adiantar o relógio...

"Só em lembrar que eu vou acordar mais cedo amanhã, dá uma preguiça", avisa a vendedora de acarajé Maria Emilia

\begin{abstract}
À Oh deste sábado (15), os relógios deverão ser adiantados em uma hora. No Sul, no Sudeste e no Centro-Oeste, o horário vigora todo ano, durante cinco meses, desde 1985. No Nordeste, a decisão de aderir fica a critério dos estados.
\end{abstract}

"Eu acho muito ruim a Bahia ficar desacoplada do horário do Brasil central, da capital Brasilia", disse o governador da Bahia, Jaques Wagner.

Metade dos baianos ouvidos em uma pesquisa concordou com o horário de verão. Quem mora nos bairros mais distantes e amanhece nos pontos de ônibus já se acostumou a acordar mais cedo para não perder o horário do trabalho. Mas, para muitos motoristas, por exemplo, adiantar o relógio significa acordar no meio da madrugada. Eles dizem que o maior problema é na hora de dormir.

"Vai dormir às $21 \mathrm{~h}$, em vez de dormir às $22 \mathrm{~h}$. Vai dormir uma hora antes, mesmo sem sono", conta o motorista Jaime Reis

Nas margens do São Francisco, duas cidades vizinhas terão situações opostas. 0 horário de verão que vigora em Juazeiro, na Bahia, vai mexer no relógio de quem mora do outro lado do rio, em Petrolina, Pernambuco.

"Eu moro aqui, mas trabalho lá em Juazeiro. Quando a gente acordar aqui eles estarão dormindo lá", diz a representante comercial Sandrine Gomes.

Gostando ou não, os baianos não perdern o bom humor

"Eu estou achando ótimo. Uma hora a menos para dormir e urna hora a mais para curtir. Nesse verão eu vou curtir muito", brinca a comerciária Laila Freitas.

horário de verão termina no dia 26 de fevereiro do ano que vem. 
Fonte: http://g1.globo.com/jornal-nacional/edicoes

Horário de verão começa à $0 \mathrm{~h}$ deste sábado (15) em 11 estados e no DF A novidade, este ano, é a inclusão da Bahia. Metade dos baianos ouvidos em uma pesquisa concordou com o horário de verão.

No início da reportagem é dito que metade dos baianos concordou com a adoção do horário de verão. Mas, por qual motivo a opinião da população baiana se divide? Esse questionamento introduz o desvelamento de sentidos presentes na reportagem. $\mathrm{O}$ trecho reflete a natureza da reportagem: dividida entre sentidos que, por vezes, sustentam o estereótipo do baiano preguiçoso, e por vezes, do baiano trabalhador. Há, pois, um atravessamento refletindo uma relação que o estereótipo da preguiça baiana mantém com um discurso oposto, o do baiano trabalhador.

Sobre isso, Zanlorenzi (1998, p.7) questiona: “(...) se os baianos trabalham tanto - e inclusive compuseram quase metade da mão-de-obra migrante para o sudeste, nos anos 30 e 40 como adquiriram o estigma da preguiça?”. Talvez a resposta ao questionamento da autora deva levar em consideração a possibilidade de uma manobra interdiscursiva resultante da combinação de duas condições de produção desse discurso: a escravidão e as ondas migratórias que partiram da Bahia em direção ao sudeste do país na busca por emprego em meados do século XX. Em ambos os momentos históricos, o baiano perderia a sua condição de trabalhador e assumiria uma caracterização oposta: preguiçoso. O resultado é a sustentação de dois efeitos imaginários sobre o baiano: o baiano trabalhador e o baiano preguiçoso.

Reflexo da representação do baiano como sujeito preguiçoso é o fato de a linguagem, a identidade e diferença serem produtos de relações sociais. Grupos sociais assimetricamente situados numa relação de poder disputam recursos simbólicos como uma das vias de acesso aos bens sociais. As identidades emergem, pois, no meio de uma arena de embates em que grupos sociais tentam garantir para si o poder de definir a identidade e marcar a diferença. Dessa forma, as identidades resultam de relações de poder.

Possenti (2010) também acredita que as identidades são produtos sociais e, quando construídas por um grupo (o Outro), por processos como redução e negativação, dão origem aos estereótipos. Sobre identidade e diferença, Possenti trabalha o conceito de simulacros, que emergem quando duas identidades são confrontadas. Segundo o autor, "o simulacro é uma espécie de identidade pelo avesso - digamos, uma identidade que um grupo social não assume, mas que lhe é atribuída de um outro lugar, eventualmente, pelo seu Outro"(POSSENTI, 2010, p. 40). Por exemplo, o simulacro da preguiça baiana corresponde exatamente à atribuição de sentidos a uma identidade pelo seu diferente, pelo Outro.

O fato de se afirmar que metade dos baianos concordou com o horário de verão, e que outra metade não foi favorável, reflete sentidos implícitos os quais, independentemente de sua ausência gráfica como materialidade discursiva, estão relacionados ao interdiscurso que, segundo Pêcheux (1999):

[...] seria aquilo que, face a um texto que surge como acontecimento a ser lido, vem restabelecer os 'implícitos' (quer dizer, mais tecnicamente, os pré-construídos, elementos citados e relatados, discursos-transversos, etc.) de que sua leitura necessita: a condição do legível em relação ao próprio legível (PÊCHEUX, 1999, p. 52).

Assim, nem todos os sentidos resultantes de uma análise discursiva são o resultado do que se encontra explicitado no texto. Há não-ditos, implícitos que comprovam a incompletude da linguagem, afinal "todo dizer é uma relação fundamental com o não dizer" (ORLANDI, 2007, p. 12).

O discurso jornalístico como um todo, e em particular o discurso do Jornal Nacional, é marcada por um não-dito sugerido a partir do que é dito. Desse modo, os efeitos de sentido 
resultam da relação entre sentidos que podem ser lidos e outros sentidos que podem ser significados, apesar de não estarem materializados graficamente na superfície de um papel.

- Os baianos sempre gostaram dos dias mais longos do verão. Mas quando se fala em adiantar o relógio...

As afirmações "os baianos sempre gostaram dos dias mais longos do verão" e "os baianos não perdem o bom humor" funcionam como um efeito de evidência, trazendo à tona uma representação amplamente partilhada. Ambas as afirmações refletem pré-construídos que confirmam a presença de estereótipos no texto.

Como se pode observar, a linguagem jornalística não é isenta do efeito do interdiscurso que fornece ao enunciador-jornalista já-ditos dos quais se apropriará para, na sequência, torná-los objetos de seu próprio discurso.

Durante o verão, a cidade de Salvador entra na "alta-temporada", período em que recebe turistas de todo o país e do exterior. É nesse período que se concentra a maioria das festas religiosas e populares (a Lavagem do Bomfim, o Carnaval, entre outras) e da iniciativa privada (como o Festival de Verão). O verão sinaliza o início de um período em que turistas procuram a Bahia para, temporariamente, se sentirem livres das obrigações e responsabilidades do trabalho. Mas, para que tudo transcorra bem, os baianos trabalham muito durante os shows, festivais, ensaios etc. No entanto, o trecho: "Os baianos sempre gostaram dos dias mais longos do verão. Mas quando se fala em adiantar o relógio..." reflete uma das formas como a personalidade baiana é representada e a sua relação com o trabalho: preferindo ócio e festas ao trabalho. Esse caráter festeiro pode ser compreendido como um desdobramento do estereótipo do baiano preguiçoso. A incompletude da frase proferida pelo repórter, materializada graficamente em forma de reticências, confirma que o texto está estruturado por meio de evidências subjacentes, e cujos efeitos de sentido decorrem da interpretação de implícitos.

Ao mergulhar na exterioridade textual, na história, o sujeito é levado a rememorar o que foi falado antes, em outros espaço e tempo. Isso é efeito do interdiscurso ou memória discursiva. Gostar de dias mais longos não significa necessariamente que se esteja disposto a adiantar o relógio em uma hora, pois isso significa que se terá de levantar mais cedo, às vezes sem que o sol tenha ainda despontado. Um povo cuja representação construída e fixada no senso comum está fortemente ligada à preguiça dificilmente estará contente em acordar mais cedo. Isso pode ser comprovado na fala de uma das entrevistadas na reportagem veiculada:

"Só em lembrar que eu vou acordar mais cedo amanhã, dá uma preguiça" avisa a vendedora de acarajé Maria Emília Bittencourt.

A vendedora de acarajé, uma figura tipicamente baiana, acaba assumindo o estereótipo do baiano preguiçoso e, tomada por um efeito de evidência, acaba expondo uma ideia que lhe é comum. Desse modo, esse trecho da reportagem fortalece o já-dito, um saber estabilizado. A fala da vendedora de acarajé reflete a assimilação de um pré-construído. Um aspecto interessante do processo de estereotipização é que os membros do grupo estereotipado adotam certas atitudes e comportamentos que condizem com as expectativas do outro, reflexo de uma assimilação de normas e outras informações recebidas sobre o seu grupo, ou, dito de outro modo, reflete o seu assujeitamento ideológico ${ }^{3}$.

\footnotetext{
${ }^{3}$ Segundo FERRÉS (1998): “Às vezes é bastante fácil perceber como alguns (ou muitos) baianos se apropriam da imagem que é feita deles em proveito próprio. Vestem o estereotipo como se fosse uma roupa, pois sentem muito bem o que o turista quer ver. A baiana de acarajé se enfeita com rendas e seu melhor sorriso, o capoeirista usa dos golpes mais acrobáticos para mostrar a sua destreza nas praças públicas, os vendedores ambulantes fazem gracejos provocando risos nos clientes".
} 
Às vezes, é bastante fácil perceber como alguns (ou muitos) baianos se apropriam da imagem que é feita deles em proveito próprio. "Vestem" o estereótipo como se fosse uma roupa, pois sabem muito bem o que o turista quer ver. A baiana de acarajé se enfeita com rendas e seu melhor sorriso, o capoeirista usa dos golpes mais acrobáticos para mostrar a sua destreza nas praças públicas, os vendedores ambulantes fazem gracejos, provocando risos nos clientes. Esses exemplos apontam para a possibilidade de o sujeito, envolvido em relações sociais, manobrar aspectos de sua identidade, de modo a atender demandas situacionais num jogo de empatias e de interesse. Albergaria (1995, p.12) chegou a afirmar que a identidade baiana "é a reprodução de um padrão imposto pela mídia. A identidade da gente não é um reflexo do que a gente é. É o cruzamento de um jogo de espelhos do que a gente é com o que o outro acha da gente". Segundo Zanlorenzi (1998, p.3-4): "a preguiça também aparece como um discurso elogioso, afirmado por certos segmentos baianos que se regozijam por não serem iguais aos que acusam de indolência. Assumem a preguiça como adjetivo da diferença. Não é uma preguiça qualquer. É a preguiça baiana, pontual, exclusiva".

Sobre a internalização dos padrões de comportamento capaz de validar os estereótipos, Ferrés (1998) diz que a ameaça é uma das bases da estereotipia e fator de sua eficácia. Isso porque, por meio da ameaça de exclusão, a estereotipia garante a submissão dos indivíduos às regras de seu jogo, ditado pelo discurso dominante. $\mathrm{O}$ sujeito acuado pela possibilidade de sua invisibilidade social e diante da possibilidade de "ter que assumir uma identidade minoritária" acaba por integrarse ao padrão estereotipado (FERRÉS, 1998, p.142). "Quem não segue a visão estereotipada da realidade oferecida pelos meios de comunicação de massas em geral, e mais concretamente, pela televisão como meio socialmente hegemônico, está ameaçado de isolamento social, de marginalização do coletivo, de expulsão da tribo" (FERRÉS, idem).

Logo em seguida, a reportagem ressalta que as regiões Sul, Sudeste e Centro-Oeste adotam o horário de verão durante cinco meses no ano desde 1985. Sabe-se que essas regiões são as mais desenvolvidas economicamente decorrentes de seu atraso econômico. Isso induz a pensar que a não disposição para o trabalho, evidenciada na resistência ao horário de verão, seria um dos motivos do atraso socioeconômico nessas ultimas regiões.

- Gostando ou não, os baianos não perdem o bom humor.

- "Eu estou achando ótimo. Uma hora a menos para dormir e uma hora a mais para curtir. Nesse verão, eu vou curtir muito" brinca a comerciária Laila Freitas.

Os dois trechos acima atualizam uma memória discursiva que fortalece no imaginário nacional a ideia que se tem da personalidade dos baianos: alegres, bem humorados e festeiros. Segundo Mariano (2009), faz parte das características idiossincráticas da baianidade um certo "modo baiano de ser" que corresponde, dentre outros aspectos, aos contornos de uma personalidade típica. Reforça-se, portanto, uma ideia do jeito baiano - dengoso, desinibido, simpático. A autora ratifica:

Os baianos típicos mais marcantes são essencialmente simpáticos, afáveis, sedutores, volúveis, espertos, muitas vezes inteligentes e desinibidos. Nas relações afetivas: o carinho, uma certa passionalidade e inconstância. Nas relações econômicas e profissionais: o despojamento, a esperteza, a inteligência, apesar da condição sempre subalterna. Nas relações sociais, a desinibição e a simpatia (MARIANO, 2009, p.71-2).

Os dois trechos anteriormente mencionados se referem se ao imaginário da personalidade baiana, sempre reforçada por certas práticas discursivas, como a telejornalística, em que é ressaltada a alegria baiana, ou mais precisamente, seu "bom humor, disposição para celebrar, entusiasmo, vibração [...]” (MARIANO, 2009, p. 128).

Entretanto, conforme já visto, a linguagem funciona pela alternância entre a paráfrase e a polissemia. Isso significa afirmar que a linguagem atua ora pela recorrência do mesmo, ora pela 
possibilidade do diferente. Entender como os discursos funcionam significa considerar um "duplo jogo da memória" que, assim como pode cristalizar, também pode tornar possível que o diferente, $\mathrm{o}$ inesperado aconteça no discurso.

Ressalta-se que a reportagem também fala do baiano trabalhador e responsável:

Quem mora nos bairros mais distantes e amanhece nos pontos de ônibus já se acostumou a acordar mais cedo para não perder o horário de trabalho. Mas, para muitos motoristas, por exemplo, adiantar o relógio significa acordar no meio da madrugada. Eles dizem que o maior problema é na hora de dormir. "Vai dormir às $21 \mathrm{~h}$, em vez de dormir às $22 \mathrm{~h}$. Vai dormir uma hora antes, mesmo sem sono" conta o motorista Jaime Reis.

A referência aqui é aos baianos que moram em bairros distantes e acordam cedo, para não perder o horário do trabalho, ou que vão dormir mais cedo para cumprir com as obrigações do trabalho. Há nessa reportagem uma movimentação de sentidos, deixando claro que os sentidos não são fixos. Essa movimentação de sentidos reflete o fato de a baianidade ser uma construção simbólica cujos sentidos vêm se adequando ao contexto sócio-histórico. Hoje, a baianidade, frente a uma nova realidade urbano-industrial, requer novas características, pois não combina, como antesacontecia, com a ideia de preguiça, que cada vez mais passa a ser um traço a se desprezar.

\section{CONSIDERAÇÕES FINAIS}

Todo texto é discursivamente heterogêneo. A reportagem deixa claro esse caráter heterogêneo de qualquer texto, atravessado que é por diferentes formações discursivas. Os efeitos de sentido depreendidos pela análise permitem concluir que há uma tensão produzida pela memória e que resulta na instabilidade e dispersão dos sentidos. Os sentidos que giram em torno do baiano trabalhador evidenciam que nem tudo é um retorno ao mesmo, a um “já-dito” ligado á preguiça baiana, pois a linguagem funciona tanto pela alternância de sentidos cristalizados quanto pela renovação de sentidos. É exatamente o esquecimento que permite que os dizeres atualizados por um "duplo jogo da memória" tragam sentidos conhecidos, fixados historicamente e tomados como naturais, ou possam inesperadamente trazer sentidos novos, por meio de deslocamentos, rupturas ou reelaborações.

Foi possível verificar como o discurso jornalístico apesar de parecer ser o reinado do atualismo, remete a fatos passados. A mídia é, por assim dizer, um espaço de memória, capaz de intervir na forma pela qual nos apropriamos dos acontecimentos. Ignorar a existência de um saber discursivo retornando na materialidade discursiva é aceitar a ilusão do sujeito como origem do seu próprio dizer, o que levaria o apagamento das determinações históricas dos sentidos e fortaleceria a impressão da transparência da língua.

Por meio da análise da reportagem foi possível observar como o Jornal Nacional constrói efeitos identitários, em especial, sobre a típica identidade baiana que abarca em sí uma difundida ideia de preguiça. Ao afirmar que constrói é porque é capaz de manter ou modificar discursos identitários, não como algo sem existência anterior, mas como um corpo que é constantemente elaborado, reelaborado e adaptado ao contexto de forma coerente. A contradição baiano trabalhador $\mathrm{x}$ baiano preguiçoso, presente na reportagem reflete o movimento que desloca as representações coletivas.

A análise feita reflete o fato de os brasileiros de diferentes partes do país serem representados no telejornal Jornal Nacional, tendo os contornos de suas identidades definidos discursivamente. Ao serem representados, são significados, pois os meios de comunicação oferecem modelos com os quais o publico possa identificar-se. Entretanto, as representações partem da visão do centro (do Rio e de São Paulo) revestido do poder de caracterizar outras identidades coletivas, como diferentes, exóticas. Os telespectadores do Jornal Nacional são quase 
que diariamente expostos a um discurso que lhes apresenta o mundo, diferentes sujeitos e alguns sentidos construídos historicamente, de modo que tudo isso contribui para a formação de sua autoimagem e do seu pensamento e ação sobre o outro.

Por fim, a contradição (baiano trabalhador x baiano preguiçoso) pode ser compreendida como condição para que qualquer formação discursiva exista e funcione, numa incessante tentativa de superação, sem nunca conseguir. É a contradição que abre a possibilidade para que uma formação discursiva possa mudar, transformar-se e garantir sua perenidade, sua historicidade.

\section{REFERÊNCIAS BIBLIOGRÁFICAS}

ALBERGARIA, Roberto. Praia vira palco no teatro do prazer. Entrevista ao jornal Linha Direta, n.51. Salvador: outubro de 1995.

COURTINE, Jean-Jaques. O chapéu de Clementis. Observações sobre a memória e o esquecimento na enunciação do discurso político. In: INDURSKY, Freda. Os múltiplos territórios da Análise do Discurso. Porto Alegre:Sagra Luzzatto, 1999. p. 15-22

Quel objet pour l'analise du discourse. Lille: Press Universitaires de Lille, 1981.

FERRÉS, Joan. Televisão subliminar. Porto Alegre: Artmed, 1998.

HENRY, Paul. Os fundamentos teóricos da "Análise Automática do Discurso" de Michel Pêcheux. Tradução de Bethania Mariani. In: GADET, Françoise; HAK, Tony. (orgs.). Por uma análise automática do discurso: uma introdução à obra de Michel Pêcheux. 2 ed. Campinas: Unicamp, 1993, p. 13-38. Tradução do original de 1969.

MARIANO, Agnes. A invenção da baianidade. São Paulo: Annablume, 2009.

ORLANDI, E. As formas do silêncio: no movimento dos sentidos. 6. ed. Campinas: Editora da Unicamp, 2007.

A Análise de Discurso em suas diferentes tradições intelectuais: o Brasil. In: INDURSKY, F.; FERREIRA, M. C. L. (Org.). Michel Pêcheux e a análise do discurso: uma relação de nunca acabar. São Carlos: Claraluz, 2005.

Discurso e texto: formulação e circulação dos sentidos. 4 ed. Campinas: Pontes, 2001.

Análise de discurso: princípios e procedimentos. Campinas: Pontes, 1999.

Terra à vista!: discurso do confronto: velho e novo mundo. Campinas, Editora da Unicamp, 1990.

PÊCHEUX, Michel. Discurso: estrutura e acontecimento. 3. ed. Campinas-SP: Pontes, 2002.

Papel da memória. In: ACHARD, Pierre [et al.]. Papel da Memória. Campinas, São Paulo: Pontes, 1999, p. 49-57.

Análise automática do discurso (AAD-69). In: GADET, Francoise; HAK, Tony. Por uma análise automática do discurso: uma introdução à obra de M. Pêcheux. Campinas: Editora da Unicamp, 1997a. 
Semântica e discurso: uma crítica à afirmação do óbvio. Tradução Eni Orlandi. Campinas: UNICAMP, 1997b.

POSSENTI, Sírio. Humor, língua e discurso. São Paulo: Contexto, 2010.

ZANLORENZI, Elisete. O mito da preguiça baiana. Tese de Doutorado em Antropologia. São Paulo: USP. 1998.

Recebido em 02/05/2017

Aceito em 24/08/2017

Publicado em 23/11/2017 